\title{
The Impact of Political Culture on the Human Rights-based Approach to Development in the Central Highlands of Vietnam
}

\author{
Toan N Dang ${ }^{1}$ \\ ${ }^{1}$ The School of Social Sciences and Psychology, Western Sydney University, Sydney, Australia \\ Correspondence: Toan N Dang, The School of Social Sciences and Psychology, Western Sydney University, \\ Sydney, Australia. E-mail: n.dang@westernsydney.edu.au
}

Received: October 9, 2017

Accepted: October 16, $2017 \quad$ Online Published: January 30, 2018

doi:10.5539/jsd.v11n1p101

URL: https://doi.org/10.5539/jsd.v11n1p101

\begin{abstract}
The Human Rights-based-Approach (HRBA) to development has been endorsed by the United Nations (UN) and development agencies as the preferable approach to development. It has the potential to adequately address poverty in the developing world and to align development work with universal instruments on human rights, such as the Universal Declaration on Human Rights (UDHR) (1948). However, while much has been written about the HRBA as a viable approach to development, little is known about how the HRBA is implemented in practice, especially in non-western settings. This paper provides empirical data from a HRBA-framed poverty reduction project conducted in two ethnic communities in the Central Highlands of Vietnam, undertaken by Action Aid International Vietnam (AAV). The results demonstrate that the adaptation of the HRBA to these two local contexts was not easy or smooth. While there are many dimensions that shape the success of development work, in this article I focus on the ways in which political culture can create obstacles to the implementation of the HRBA. The article concludes by recommending some strategies that work to ameliorate these concerns.
\end{abstract}

Keywords: development, empowerment, the Human Rights-based Approach (HRBA), participation, poverty reduction, political culture, Vietnam

\section{Introduction}

The Human Rights-based-Approach (HRBA) to development has been endorsed by the United Nations (UN) and development agencies as the preferable approach to development. It has the potential to adequately address poverty in the developing world and to align development work with universal instruments on human rights, such as the Universal Declaration on Human Rights (1948) (Scheinin \& Suksi 2002; Uvin 2007). However, the extent to which HRBA are able to successfully adapt to local contexts - particularly in developing countries such as Vietnam-remains under-explored. This paper provides an example of how the HRBA is implemented in the local context of the Central Highlands of Vietnam by examining the case study of a poverty reduction project framed as an HRBA model.

The HRBA to development is centered on the principles of participation, empowerment, and accountability (Scheinin \& Suksi 2002). It is claimed that these principles are key to sustainable development for they have the ability to promote and strengthen development outcomes (Schmitz 2012; (Moser 2001). Advocates of HRBA suggest that local people should be the key drivers of the development process (Kindornay, Ron \& Carpenter 2012; Schmidt \& Traub 2009). This is to assist the local communities in understanding the project and its objectives (Connell 2010). A fundamental understanding about the process is essential for them, for it not only allows them to better participate in the development process, but also enables them to hold relevant stakeholders accountable (Gaventa 2002). On another level, local people have the chance to work together and with other stakeholders, such as project staff, donors, and the government. While this is a good chance for them to build a shared understanding with other stakeholders, it also allows these local members to be empowered (Gaventa 2002; Narayan 2002). Through active engagement in the project, community people can further strengthen their capacity and develop important skills (such as communication, questioning, negotiating, project monitoring, and management). Importantly, such approaches permit both individuals, and the community as a whole, to develop key skills (Ife 2002; Islam \& Sultana 2005; Narayan 2002). These skills provide them with power to better engage with local structures and pursue their own development (Sen 2005). This means that the HRBA to development empowers local communities in development, enabling them to better function in the process 
(Scheinin \& Suksi 2002).

Given the HRBA approach links poverty to power, it is assumed that (UNDP 2006), in order to adequately resolve poverty in the community, the issue of human rights must be addressed (Lennox 2012; Pogge 2008). The HRBA stresses that rather than treating local people as recipients of development outcomes, local people must be placed at the heart of the development process as principle stakeholders with the ability to shape and make their own decisions (Clark 2002; UNDP 2003). They must be adequately empowered to participate in, question and hold accountable public stakeholders in the community and outside it for decisions these stakeholders have made that affect local livelihoods (Kindornay, Ron \& Carpenter 2012). However, the theoretical underpinnings of the HRBA to development are often not well understood by agencies charged with their implementation. This results in a "top-down" approach to development (Schmitz 2012), which merely aims to deliver materials for the purpose of survival and ignores local participation in development (Adrianna 2012). Instead, a bottom-up approach should be adopted, whereby local key stakeholders, such as the community, have a chance to shape and decide on their own development in their own rights.

Local views provide an insight into the way that local political culture can shape how the HRBA is implemented in the community. An empirical research project was conducted in 2015 in two geographical areas of the Vietnam Central Highlands. ${ }^{1}$ Qualitative methods were used to gather in-depth insights from thirty-four participants, where the aim was to explore the local views and experiences of a HRBA-framed poverty-reduction project. The study included interviews and observational data, and a combination of data added depth to the data collected and provided multiple perspectives to the research (Berg 2004; Hay 2010).

This finding from this study suggest that, in order to effectively implement the HRBA to development in the communities in the Central Highlands of Vietnam, greater attention needs to be paid to addressing local contemporary political culture. Without addressing the specific political culture, significant obstacles to the successful implementation of the HRBA remain. This paper is structured into three sections. Section one provides an overview of the contemporary political culture in Vietnam. This section also presents a discussion of the Doi Moi policy (Renovation) that was adopted by Vietnam in the 1980s, and considers the structural changes that enabled the transition from a centrally planned economy into a market economy (Forbes et al. 1991).

The second section of this paper explores the relationship between political reform and development, with a particular focus on exploring the local political culture and the way in which this culture can work as an obstacle to the AAV project. This section reflects on my case study of a HRBA-framed poverty reduction project implemented in the two ethnic minority communities in the Central Highlands of Vietnam.

Finally, the paper summarizes the implications of the case study for the AAV project and also for other development organizations that aim to implement the HRBA to development in local communities.

\section{Vietnam: The Contemporary Political Background}

Vietnam has a war-torn past that has negatively affected many sectors of society, and particularly those in the highland communities. Following decades of war against the American-backed government in the South, Vietnam was unified as a state in 1975 (Kingsbury 2001). From a country stricken in persistent poverty prior to the 1990s, Vietnam has now become a low middle-income country with a steady annual growth of seven percent. The country has emerged as one of the fastest growing economies in the South-east Asian region (Boothroyd \& Pham 2000; Gainsborough 2010).

The state of Vietnam is ideologically guided by the Vietnamese Communist Party (VCP), which is the only party in the country (Guan 2004). However, I argue that it is not correct to frame Vietnam today as a communist country, at least in a traditional sense. This is in part because Vietnam has now become a market economy in its fullest sense, with the private sector and other non-state sectors-such as foreign investment and multi-national enterprises - playing a major role in the economy (Abuza 2001; Holmes 1997). The government has retreated to focus on macro issues, such as policy making (Abuza 2001). The government of Vietnam is comprised of the National Assembly (the legislative organ) and the Prime Minister's Office and the ministries or committees under its purview (the administrative organs) (Guan 2004). There are also mass organizations ${ }^{2}$ that purport to

\footnotetext{
${ }^{1}$ The study was undertaken in two ethnic minority communes (communities?) in the Central Highlands of Vietnam. Thirty-four key informants from a wide range of stakeholders, such as villagers, AAV project staff, local leaders at commune and district levels, representatives from local mass organizations (such as Women's Union (WU) and Youth Unions (YU)), participants from local and international NGOs, representatives from the local University, and a provincial Department (Department of Agriculture and Rural Development), were recruited to participate in the project.

${ }^{2}$ Mass organizations in Vietnam are not independent entities, but are an effective part of the political structure. While they are intended to represent community groups, such as women, farmers, and youth, they are not open to public membership.
} 
represent different interest groups, such as women, youth, farmers, religious groups, and workers.

The relationship between the State (the VCP party and the government) and society in Vietnam can be characterized as two distinct and separate entities (Kerkvliet, Benedict J. Tria 1995). However, on another level there is still a blurring of boundaries between these two entities, such that they often intermingle (Kerkvliet, Benedict J Tria 1995). Some scholars have highlighted the unequal distribution of power between the state and society, claiming that there seems to be too much ascribed to the state and too little to society (Abuza 2001; Guan 2004; Kingsbury 2001; Trotsky 2001). In addition, many civil groups are invisibilised in society, and this limits their capacity to speak out for certain communities. It is therefore difficult for these groups to effectively operate independent of the government. Guan (2004) argues that this is how a socialist country with a ruling communist party is typically structured.

In discussing the relationship between the state and society in Vietnam, Thayer (2008) claims that the relationship has significantly changed since the Doi Moi policy, which I will discuss in detail in the following section. This is in part because the role of civil society has become progressively important in the political operations in Vietnam (Guan 2004). The media, which has enjoyed greater space and freedom, has become more critical of the government. Religious groups have also started to resist government interference, and marginalized groups (such as ethnic minorities like the Ede people), have demanded greater equality (Thayer 2008). The number of dissidents has also grown, and they are more critical of the government, with demands for greater intellectual freedom and independence (Guan 2004; Thayer 2008).

\section{Vietnam under the Doi Moi Policy (Renovation)}

Vietnam adopted the Doi Moi in the late 1980s (Forbes et al. 1991; Pham 2011). Central to the Doi Moi was the liberalization of the economy, replacing the previous central planning strategy that had been dominant for decades in Vietnam (Abuza 2001; Kingsbury 2001; Mattner 2004). By adopting the Doi Moi, Vietnam has undergone a strategic structural move towards a more democratic and participatory country (Mattner 2004).

In the economic sphere, Vietnam emerged as one of the few countries to have been impressively successful in poverty reduction, and to have meaningfully contributed to the implementation of the UN-initiated Millennium Development Goals (MDGs) in 2000 (Arsenio et al. 2003; Fritzen 2002; Mattner 2004). Vietnam today is one of the fastest-growing market-based economies in the South-East Asia region, with a steady growth rate of seven per cent a year (Arkadie \& Mallon 2003; Arsenio et al. 2003; Baulch et al. 2007; Niimi et al. 2004).

Thayer (2008) claims that the adoption of the Doi Moi has led to important changes in Vietnamese society beyond economic development alone. According to Thayer (2008), Vietnam progressively opened up to the outside world socially, culturally, and politically, especially in terms of economic sphere. One can realize that Vietnam has adopted Western principles in economic development, while trying to maintain its socialist oriented strategy. This has in part resulted in a strong flow of foreign investment, where government aid agencies and international NGOs have come into the country to assist with local development (Thayer 2008). Examples of these groups include the AAV, Care International, Save Children and Oxfam (Thayer 2008). Each organization arrived with its own approach to development, such as the participatory approach and the livelihoods approach (Thayer 2008). Organizations such as the AAV, Care International, and Oxfam, chose to implement the HRBA to development (Kindornay, Ron \& Carpenter 2012).

The 1990s recorded an explosion of organizational activity at all levels in Vietnam (Thayer 2008). According to Thayer (2008), the role played by the Vietnamese state in the economy also changed; rather than being directly involved in the economy as the dominant stakeholder, as it was prior to the Doi Moi, the state now focused on creating a more liberal economic and legal framework to free the market.

However, claims that current political culture in Vietnam may still make it hard for the community and social groups to gain an equal space and opportunity to better engage with the political structure (Avonius \& Kingsbury 2008; Kingsbury 2001). Organizations may find it difficult to effectively contribute to society, especially when they are critical of government (Abuza 2001; Kingsbury 2001; Trotsky 2001). These characteristics of the local political culture are viewed as contextual specificities that present potential challenges to the implementation of the HRBA to development (Reichert 2007). While the HRBA aims to approach development from the "bottom-up", placing local people at the centre of development, (Kindornay, Ron \& Carpenter 2012; Scheinin \& Suksi 2002), development is "top-down" under a centralizing governing approach. The difference between the "top-down" approach to development and associated political culture discussed above, and the HRBA to development, has important implications for the AAV project examined in the next section, particularly for its attempt to successfully implement the key principles of HRBA in the community. 


\section{The Relationship between Political Reform and Development}

While economic indicators suggest that there has been impressive change in economic development, scholars are more critical of the extent of the changes in the sphere of politics (Kingsbury 2001; Mattner 2004; Thayer 2008). For example, Kingsbury (2001) notes that not much has happened in the sphere of political structures in Vietnam.

According to Kingsbury (2001), although lower levels of government, such as the province, city, district and commune levels, have been provided with progressive autonomy to make their own development decisions, Vietnam to a certain extent can still be characterized as a centralizing state with power ultimately resting with the central government in the capital Hanoi (Kingsbury 2001; Trotsky 2001). For example, while there is a consultation process which takes into account local voices, lower levels of government rely on the central government for approvals for strategic developmental decisions. This not only makes it difficult for the lower levels of government to shape and decide on their own development strategies, but also makes it hard to implement the central government-initiated decisions or strategies because, in many cases, these strategies do not adequately reflect local specificities. Some scholars claim that the sustainability of development can be jeopardized by a centralized development process which is less participatory and democratic (Connell 2010; Hibbard \& Tang 2004; Klepeis 2003; Sachs 2012). A centralized development process fails to appreciate local, nuanced, and contextual factors.

Clearly Vietnam does not have the same centralized political structure that it had before the Doi Moi (Arkadie \& Mallon 2003; Forbes et al. 1991). Rather than portraying Vietnam today as a centralized structure, Trotsky (2001) describes Vietnam as a paternalistic state where the government tends to believe that it can take effective care of the local communities. As a paternalistic state the government tends to act on the basis of its own assumptions rather than through a meaningful participatory consultation process (Gainsborough 2010). Related to this paternal approach, research shows that a conventional "top-down" approach to development remains dominant in the country's development strategies (Arsenio et al. 2003; Fritzen 2002; Nguyen \& Nguyen 2011).

A paternalistic governance approach may succeed in providing a rapid socio-economic development strategy, but it is unable to sustain long term-development (Trotsky 2001). This is because such approaches lack the active participation of local people, and the development outcomes are not appropriate or sustainable (Hopper 2012; Trotsky 2001). Moreover, a paternalistic strategy often regards economic growth alone as the ultimate aim of development while neglecting other values, such as sustainability, equality, participation, and accountability (Trotsky 2001).

\section{Findings from the Case Study of the AAV Poverty Reduction Project in the Central Highlands of Vietnam}

To conduct this research, I interviewed 34 local participants who each had a stake in the outcomes of the HRBA-framed poverty reduction project. In order to understand the enormous complexities and differing needs of the local communities, I decided to select a wide range of stakeholders to ensure I was getting a multi-faceted perspective. These participants included local villagers in the two project communities, representatives from local mass organizations at commune and district levels, political leaders at commune and district levels, the AAV project staff, representatives from public institutions (Tay Nguyen University and the Department of Agriculture and Rural Development), and representatives from international and local non-governmental organizations (NGO). Such a wide range of views is important for it provides a broad picture of how the HRBA to development has been implemented.

\section{The Human Rights-Based-Approach: A Sensitive Subject}

Examination of the case study demonstrates that adapting a HRBA approach to development in the Central Highlands of Vietnam is challenging. There are a whole range of contextual specificities that form obstacles to the HRBA. Local political culture is a potential obstacle. As observed by the participants:

\section{I think that you have to be careful when implementing the HRBA in the local region because it is sensitive (Duc) $)^{3}$. \\ Well, please do not use the audio-recorder. We can talk about the HRBA, but I don't want our conversation to be recorded (Nguyen) ${ }^{4}$.}

These participants clearly implied that the subject of HRBA is not a part of the common language in the

\footnotetext{
${ }^{3}$ To ensure confidentiality of participants, I gave all the participants fictitious names. Duc is the representative of the University.

${ }^{4}$ Nguyen is a district leader and has participated in the AAV project for many years on behalf of the district.
} 
community, and they were reluctant talking about the HRBA. While this indicates the sensitivity of the HRBA to development, this could mean that these participants understand what the HRBA is about. They were aware that such the sensitivity can be exposed as a potential impediment to the implementation of the HRBA in the communities. My fieldwork shows that most participants tended to avoid talking about the topic of human rights and some refused to have conversations on this topic audio-recorded.

My fieldwork also demonstrated that it was not only local leaders who perceived the topic as sensitive, but also the HRBA project staff. As Le observed:

I think that the HRBA is not a common language in the community. It could be viewed as sensitive. Therefore, we do not often refer to it when implementing the project $(L e)^{5}$.

This participant not only reinforces the view that the subject of human rights or the HRBA to development is a sensitive topic to talk about, but also reveals that the HRBA is not effectively implemented in a local context. This is because one cannot implement the HRBA without properly naming and explaining about it. While this adds to the difficulty facing the AAV project in the communities, this suggests that, in order to effectively implement the HRBA to development, it is fundamental that all relevant stakeholders, especially local leaders and the project staff, have a shared understanding of the HRBA as a preferable approach to development that has the ability to better address poverty in the communities.

In order to achieve a shared understanding of the HRBA to development, it is advisable to begin with constructive discussions around the topic of human rights and how human rights is linked to development and that promoting human rights as a central component of development is not necessarily a political objective, but can foster development. It is essential that human rights or the HRBA should be viewed by all stakeholders, such as local leaders, project staff and villagers, as a concept and practice that can be openly discussed in the communities without fear. This all needs to be viewed as a foundational step for the AAV project to better enable its implementation of the HRBA in communities.

Human rights and HRBA approaches remain an unfamiliar and largely unknown concept in the community. When local people interviewed had heard of human rights, it was in the context of a particular right (such as women's rights or the right to land). As observed by the participants:

We have heard about the HRBA, but we do not know what it is really about (H'Trinh) ${ }^{6}$

I think the HRBA is about women's rights and child rights (H'Khuong)'.

Only until recently have I heard of the HRBA to poverty reduction. I think it is about the right to land (Hoang $)^{8}$

While all participants here have indicated that they have heard of rights in relation to a particular issue, my fieldwork showed that very few participants had a fundamental understanding about the concept of rights in general. This suggests that the concept of human rights or the HRBA to development remains an unfamiliar and largely unknown topic in the communities. This presents a challenge for the AAV project in the communities as it is hard to implement the HRBA to development when it is not well understood or perceived by some as a sensitive subject. When the HRBA is not well understood, or perceived as a sensitive subject to talk about, it is impossible to know if the HRBA is effectively implemented or how it has contributed to addressing poverty in the communities. It also remains uncertain how the local communities will react to the implementation of HRBA's when they are unfamiliar with them.

\section{Participatory Political Culture}

One of the key principles any HRBA project aims to implement is participation. My research shows that the contemporary political culture in the communities can create an inadequate participatory culture in development. As I discussed earlier, the conventional "top-down" approach to development remains a dominant approach in Vietnam and has been criticized as paternalistic (Tonkens \& Duyvendak 2003). Under such an approach, it is hard to promote local participation. Local people continue to be excluded from the development process, and

\footnotetext{
${ }^{5}$ Le is a male participant. While he does not come from any of the project communities, he is in charge of the implementation of the project in the district. He has a University degree in Agriculture.

${ }^{6} \mathrm{H}$ ' Trinh is a female villager. She lives in one of the two project communities. She has participated in the project for several years.

${ }^{7} \mathrm{H}$ ' Khuong is a female villager. She lives in one of the two project communities and has participated in the project for many years.

${ }^{8}$ Hoang is a male participant. He has a PhD degree. He represents DARD. While he does not directly participate in the project, he has experiences in development projects in the Central Highlands. He currently works as an Asian Development Bank funded project on agriculture diversity in Daklak province on behalf of DARD.
} 
were even treated as immature and incapable recipients of the development outcomes (Cooke \& Kothari 2001; Tonkens \& Duyvendak 2003). Rather than including local people in the decision-making process, the local government tends to make decisions on their behalf, and then informs local people of the decisions that have been made for them. This is demonstrated in the interviews I had with, H' Loan, a villager:

We do not know much about the government-initiated projects, such as 135. They just informed us of the project. I think the projects are very top-down (H'Loan).

This approach to development has marginalized local people from the development process. While this could reflect a dominant development culture in the communities, this shows a considerable challenge for the AAV project in its attempts to implement the HRBA, especially to promote local participation. Judged through the lens of rights, it can be claimed that the local people's right to participate in development has been denied (Sengupta, Neg \& Basu 2005). This also means that the path that needs to be taken to align development work in practice with universal instruments on human rights, such as the UDHR (1948), remains a challenge.

Given the centrality of participation to the HRBA to development, the AAV project must work to address the lack of a participatory culture in the communities in which it works. However, my fieldwork suggests that the promotion of a participatory culture in the community will not be easy or smooth. It will require a great deal of time, resources, and special expertise. It is not easy to dismantle an entrenched "top-down" approach to development and replace it with a racially different HRBA to development. This is because not only does the government need to racially change the way it does development work, but also local people need to be brought on board and take on a principle role in development.

\section{The Role of Community Organizations in Participation}

In my exploration of the local political culture as a potential obstacle to the implementation of the HRBA, I realized that organizational structure is another obstacle that needs to be addressed if the HRBA is to be successfully adapted to the local communities as a poverty reduction strategy. This is because local people lacked an organization to participate in, while the current structure does not have a meaningful space for them to engage with.

Through their HRBA work, the AAV project has developed partnerships with local organizations, such as district and commune Women's Union, Farmers' Associations, and Youths' Union. These organizations have provided technical assistance to the project. As one of the participants, Ngoc, observed:

We frequently participate in the project at its invitation to provide training and implementing the activities (Ngoc) $)^{10}$

At first glance this involvement of these community organizations might suggest that the project was paving the way for sustainable development through building local ownership and partnership with local organizations. However, further investigation into the political structure in the communities I worked with suggested this is not so straightforward.

These partnered organizations are typically described as mass organizations of the communities. They were established by the government to represent local interest groups in the communities, such as women, farmers, and youth. Yet my research shows that these organizations do not truly represent the community as claimed, and this is mirrored in other research (see: REF, REF). In fact, they are effectively part of the current political structure (Kerkvliet, Benedict J. Tria 1995). Scholars argue that the mass organization in Vietnam primarily serves to ensure the effective implementation of the party lines and state policies in society (Kerkvliet, Benedict J. Tria 1995). This adds a further dimension to the challenges presented by the political culture at the local level in the communities I worked with in Vietnam and another obstacle to the successful implementation of the HRBA to development.

Though based in the communities and labeled as mass organizations, these organizations are not open to public membership or truly represent the community people in the local structure (Mattner 2004). According to Kerkvliet (1995), under such a political culture, the community does not have sufficient space to voice their views or to make their own decisions. Local people therefore lack organizations to enable participation. This has a significant implication for the AAV project as local organizations play a key role in development, not only by helping to get local people involved in development projects, but also in relation to long-term empowerment.

\footnotetext{
${ }^{9} \mathrm{H}$ ' Loan is a female villager. She lives in one of the project communities. She has participated in the project for many years.

${ }^{10} \mathrm{Ngoc}$ is a male participant. He represents the district YU. He has participated in the project and delivered trainings at the request of the project.
} 
Having an organization that truly represents the community will better enable local people to engage with local structures. They can gather and discuss a solution that suits them best. Moreover, as an organization working towards achieving a shared goal, local people become more powerful. This not only allows them to better engage with local structures, but also to create accountability.

My fieldwork shows that, while the AAV project aims to promote local people to effectively participate in the development process as strategic actors, and empower them so that they can better engage with the local political structure and hold public institutions in the community and outside it to account, it is hard for the project to do so in the absence of an organization that truly represents local people. This could be viewed as a gap that the AAV project needs to fill in order to better enable the implementation of the HRBA in the communities. Yet, if the AAV project seeks to fill this gap, it may find itself challenging local and district power structures.

In part in response to this the gap, the AAV project has established some community groups, which are referred to by the project as groups of preferences. However, my fieldwork suggests that these groups were primarily set up to implement the short-term activities of the project — such as training in agricultural skills - rather than paving the way for local people to better engage with the local structure in the long-term. After establishing these groups, the AAV project did not pay sufficient attention to strengthening the groups. As a result, most of these groups quickly fell apart. More importantly, these groups were not linked into a network in the communities. They were independent of one another. As one of my participants told me:

Yes, we have different groups in the community, such as group of coffee cultivation, group of chicken etc. However, these groups are not operational effectively for they are not taken good care of (Y Hoan $)^{11}$.

The group of preferences were not intentionally established as a place where local people would be better linked and networked together, which would give them additional power to engage with the local structure. They are not political groups. This suggests that the path the AAV project has taken to transform local people from powerless stakeholders into powerful actors is far from complete. While the community lacks an organization, or set of interlinked organizations that truly represent the local people, the project paid little attention to this. This means that if the HRBA is to be seriously taken into consideration as a preferable approach to poverty reduction in the community, it is essential that local people have an organization of their own to participate or at least one that truly represents them in the local structure. These organizations or groups must be equipped with sufficient resources and capacity to effectively tackle development issues in the communities, and especially to better engage with and eventually hold state institutions accountable for the decisions they make. This is central to the HRBA to development. As Scheinin, M \& Suksi, M (eds) (2002) note, the HRBA aims to transform the local institutional system, simplifying it and making it more accessible to the local people. In other words, the HRBA aims to empower local people so that they can question, engage, negotiate, and most importantly, hold the system accountable.

\section{Adapting the HRBA to the Local Context}

Community development models offer one way in which the AAV project could adapt the HRBA in the local context of Vietnam in response to the challenges highlighted above. Rather than households-based initiatives, these models offer an economic development strategy for local communities that politically empowered local people. Additionally, the community development model might better reflect collectivist values or culture that development projects implemented after the Doi Moi in the 1980s.

The community-based development model provides local people with an opportunity to work together towards a shared economic development goal. More importantly, this model potentially fits with the key HRBA principles of participation, empowerment and accountability that the AAV project seeks to implement in the community. Ortmann \& King (2007) argue that cooperatives can provide a means for the community to challenge their current social and economic marginalization, especially in a political culture that is not adequately participatory. By definition, an agricultural cooperative is an autonomous association of members voluntarily coming together and working together to satisfy their social, cultural and economic needs through a collectively-owned and democratically-managed enterprise (Ortmann \& King 2007).

Agricultural cooperatives are not new to Vietnamese farmers. In fact, such initiatives have prevailed in Vietnam for a long time (particularly in the 1960s to late 1980s) (Desai 2005; White 1985). According to White (1985), the agricultural cooperatives established in the period from the 1960s to the 1980s were planned cooperatives. They formed a central connection between local farmers and the central government. However, the connection failed to enable greater participation in development. As Vo (1992) suggests, members of the cooperatives were

\footnotetext{
${ }^{11} \mathrm{Y}$ Hoan is a male villager. He is from one of the two communities and has participated in the project for several years.
} 
not allowed to shape or make their own decisions, such as what to produce, what/when to sell, how much to sell, and so on. Rather, they had to rely wholeheartedly on the decision-making of the central government. These are not the kind of cooperatives I am proposing here as a response to the contemporary political culture in the communities.

In contrast to centrally planned cooperatives, the type of cooperative I have in mind would potentially fit well with the principles of a HRBA to poverty reduction. It is based on a set of key principles, which include voluntary association, open membership, democratic member control, member economic participation, autonomy and independence, provision of education, training and information, cooperation among cooperatives, and concern for the community. This set of principles mobilizes individuals to take control of their lives. This type of cooperative is totally autonomous, community-managed, and independent of government. If the AAV project helps local people to develop this type of cooperative, it could be a potentially effective empowering initiative.

When working together in a cooperative, local people can be empowered through their everyday active involvement in the cooperative work. Mutual learning is an important characteristic of this type of cooperative, thus a cooperative could be allied with other cooperatives in the area to form a larger network. This further enables local people to better engage with the local political system.

In the sphere of economic development, Eversole, Mcneish, and Cimadamroe (2005) and White (1985) argue that setting up this type of cooperative, local villagers have a chance to work together in a well-connected group towards a collective development objective. Narayan's (2002) research suggests that through the process of working together in a cooperative, the cooperative members stand a better opportunity to participate in the competitive market economy. For example, they can better negotiate and then challenge other players in the market regarding a better price for agricultural products.

Another example of community-based development is a community laundry. A community based laundry is important to consider as along with political culture it addresses the issue of gender inequality. My fieldwork confirms much research showing that gender remains an obstacle to development (Kabeer 2005; Powell 2005). Local women are overwhelmed with work; they participate in doing work in the field with men, while also having to fulfill unpaid housework, such as cooking and washing. This prevents many women from participating in community activities.

My field observation combined with my personal experience working for an NGO in Vietnam suggests that a community laundry may be an effective development initiative for local women. While participating in the laundry, local women have the chance to develop and strengthen their social capacity through exchanging life stories and/or the problems they each have encountered. More importantly, they can also share how they overcome the problems. Together, they can also work out a strategy to deal with potential problems facing local women. This may work as a form of empowerment. More importantly, it shows that a community-based development model fits with the HRBA to poverty reduction that the AAV project implements in the communities.

\section{Conclusion}

Although widely claimed as a universal approach to development, it is important to realize that the implementation of the HRBA to development in practice is quite complicated. One area that requires particular attention is the local political culture.

In this paper, I have suggested some of the ways in which local political culture can become an obstacle to the successful implementation of the HRBA to development in Vietnam. Building on this, I suggest that to effectively implement the HRBA in the local context, attention must be paid to addressing the local political culture (Forsythe 1989; Morgan \& Turner 2009; Reichert 2007). Of course, the extent of the intervention required will depend on how enabling the local political culture currently is. This has important implications not only for the AAV project under study here, but also for development agencies that intend to implement the HRBA to development in the community elsewhere in Vietnam and around the world.

I have suggested community development models, such as agricultural cooperatives, as one of the ways in which the AAV project and other agencies might respond to the challenges associated with the political culture. These models can be an effective empowering strategy, while they can also function as an effective economic development model. Applying these models not only provides a potential for local people to effectively participate in development process, but also an opportunity to better align development work with universal development instruments on human rights, such as the UDHR (1948). 


\section{References}

ADDIN EN.REFLIST Abuza, Z. (2001). Renovating politics in contemporary Vietnam. Lynne Rienner Publishers.

Arkadie, B. V., \& Mallon, R. (2003). Vietnam: a Transition Tiger? The Introduction of Doi Moi. ANU E Press.

Balisacan, A. M., Pernia, E. B., \& Estrada, G. E. (2003). Economic Growth and poverty Reduction in Vietnam. ERD Economics and Research Department, Asian Development Bank.

Baulch, Chuyen, T., Haughton, D., \& Haughton, J. (2007). Ethnic Minority Develpment in Vietnam. Journal of Development Studies, 43(7), 1151-76. https://doi.org/10.1080/02673030701526278

Berg, B. L. (Ed.). (2004). Qualitative Research Methods. Library of Congress Cataloging-in-Publication Data, USA.

Boothroyd, P., \& Pham, N. X. (Eds.). (2000). Socioeconomic Renovation in Vietnam: The Origin, Environmental Impact of Doi Moi. Intenational Development Research Center and Institute of Southeast Asian Studies, Ottawa.

Connell, D. (2010). Participatory Development. Development in Practice, 7(3), 248-59.\# https://doi.org/10.1080/09614529754486

Cooke, B., \& Kothari, U. (Eds.). (2001). Participation" The New Tyranny? Zed Books Ltd, London.

Desai, D. R. S. (Ed.). (2005). Vietnam: Past and Present. Westview Press, US.

Forbes, D. K., Hull, T. H., Marr, D. G., \& Brogan, B. (Eds.). (1991). Doi Moi: Vietnam's Renovation Policy and Performance. Department of Political and Social Change: Research School of Pacific Studies, Australian National University, Canberra.

Forsythe, D. P. (1989). Human Rights and Development. Timothy M. Shaw edn, The Macmillan Press LTD. https://doi.org/10.1007/978-1-349-19967-9

Fritzen, S. (2002). Growth, Inequality and the Future of Poverty Reduction in Vietnam. Journal of Asian Economics, 13(5), 635-57. https://doi.org/10.1016/S1049-0078(02)00173-2

Gainsborough, M. (2010). Present but not powerful: Neoliberalism, the State, and development in Vietnam. Globalizations, 7(4), 475-88. https://doi.org/10.1080/14747731003798435

Gaventa, J. (2002). Exploring citizenship, participation and accountability. IDS Bulletin, 33(2). 1-14. https://doi.org/10.1111/j.1759-5436.2002.tb00020.x

Guan, L. H. (Ed.). (2004). Civil Society in SouthEast Asia. Institute of SouthEast Asian Studies, Singapore.

Hay, L. (Ed.). (2010). Qualitative Research Methods in Human Geography. Oxford University Press Canada, Don Mills, Ontario.

Hibbard, M., \& Tang, C. C. (2004). Sustainable Community Development: A Social Approach from Vietnam. Journal of the Community Development Society, 35(2), 87-104. https://doi.org/10.1080/15575330409490134

Holmes, L. (1997). Post-Communisam. Polity Press, UK.

Hopper, P. (2012). Understanding Development. Polity Press, Cambridge.

Ife, J. (2002). Community Development. Pearson Education Australia Pty Limited, French Forest NSW.

Islam, N., \& Sultana, N. (2005). Role of NGOs in empowering the vulnerable women: A study on ACD. Asian Affairs, 27(4), 24-40.

Kabeer, N. (2005). Gender Equality and Women's Empowerment: A Critical Analysis of the Third Millenium Development Goal 1. Gender and Development, 13(1), 13-24. https://doi.org/10.1080/13552070512331332273

Kerkvliet, B. J. T. (1995). Village-State Relations in Vietnam: The Effect of Everyday Politics on Decollectivisation. The Journal of Asian Studies, 54(2), 396-418. https://doi.org/10.2307/2058744

Kindornay, S., Ron, J., \& Carpenter, C. (2012). Rights-Based Approaches to Development: Implications for NGOs. Human Rights Quarterly, 34(2), 472-506. https://doi.org/10.1353/hrq.2012.0036

Kingsbury, D. (2001). South-East Asia: A Political Profile. Oxford University Press, Australia. 
Klepeis, P. (2003). Development policies and tropical deforestation in the southern Yucatan peninsula: Centralized and decentralized approaches. Land Degradation \& Development, 14(6), 541-61. https://doi.org/10.1002/ldr.583

Mattner, M. (2004). Power to the people? Local governance and politics in Vietnam. Environment and Urbanization, 16(1), 121-8. https://doi.org/10.1177/095624780401600110

Morgan, R., \& Turner, B. S. (Eds.). (2009). Interpreting Human Rights. Routledge Advances in Sociology New York.

Moser, C. (2001). Livelihood Security, Human Rights and Sustainable development. Overseas Development Institute, London.

Narayan, D. (Ed.). (2002). Empowerment and Poverty Reduction. The World Bank, Washington.

Nguyen, P. T., \& Nguyen, D. T. (2011). Actions for Sustainable Policy of Poverty Alliviation in the Informal and Non-Agricultural Sector in Rural Areas in Vienam. South East Asia Paper, 18(2), 377-83.

Niimi, Y., Vasudeva, D., \& Winters, A. L. (2004). Rice reform and poverty in Vietnam in the 1990s. Journal of the Asia Pacific Economy, 9(2), 170-90. https://doi.org/10.1080/1354786042000207326

Ortmann, G. F., \& King, R. P. (2007). Agricultural cooperatives I: History, theory and problems. Agrekon, 46(1), 18-46. https://doi.org/10.1080/03031853.2007.9523760

Pham, T. H. T. (2011). Doi Moi (Renovation) and Higher Education Reform in Vietnam. International Journal of Educational Reform, 20(3), 210-25.

Pogge, T. (Ed.). (2008). World Poverty and Human Rights. Polity Press, UK.

Powell, M. (2005). A Rights Based Approach to Gender Equality and Women's Rights. Canadian Journal of Development Studies, 26(1), 605-17. https://doi.org/10.1080/02255189.2005.9669101

Reichert, E. (Ed.). (2007). Challenges in Human Rights. Colombia University Press, New York.

Sachs, J. D. (2012). From millennium development goals to sustainable development goals. The Lancet, 379(9832), 2206-11. https://doi.org/10.1016/S0140-6736(12)60685-0

Scheinin, M., \& Suksi, M. (Eds.). (2002). Human Rights in Development: Empowerment, Participation, Accountability and Non-Discrimination: Operationalising a Human Rights Based Approach to Development. Martinus Nijhoff Publishers: Nordic Human Rights Publications, Oslo.

Schmidt, G., \& Traub. (2009). The Millennium Development Goals and Human Rights-based Approaches: Moving Towards a Shared Approach. The International Journal of Human Rights, 13(1), 72-85. https://doi.org/10.1080/13642980802532374

Schmitz, H. P. (2012). A human rights-based approach (HRBA) in practice: Evaluating NGO development efforts. Polity, 44(4), 523-41. https://doi.org/10.1057/pol.2012.18

Sengupta, A., Neg, A., \& Basu, M. (Eds.). (2005). Reflections on the Rights to Development. Sage Publications New Delhi Thousand Oaks London, UK. https://doi.org/10.4135/9788132102144

Thayer, C. A. (2008). One party rule and the challenge of civil society in Vietnam: Remaking the Vietnamese State: Implications for Viet Nam and the Region, City University of Hong Kong; 21-22 August; Hong Kong. City University of Hong Kong.

Tonkens, E., \& Duyvendak, J. W. (2003). Paternalism - Caught between Rejection and acceptance: Taking Care and Taking Control in Community Work. Community Development Journal, 38(1), 6-15. https://doi.org/10.1093/cdj/38.1.6

Trotsky, L. (2001). Politics In Vietnam. Renovating Politics in Contemporary Vietnam, p. 9.

UNDP. (2003). Poverty Reduction and Human Rights: A Practice Note.

UNDP. (2006). Poverty, Unemployment and Social Exclusion. Croatia.

Uvin, P. (2007). From the right to development to the rights-based approach: how 'human rights' entered development. Development in Practice, 17(4-5), 597-606. https://doi.org/10.1080/09614520701469617

White, C. (1985). Agricultural Planning, Pricing Policy and Co-operatives in Vietnam. World Development, 13(1), 97-1. https://doi.org/10.1016/0305-750X(85)90068-3 


\section{Copyrights}

Copyright for this article is retained by the author(s), with first publication rights granted to the journal.

This is an open-access article distributed under the terms and conditions of the Creative Commons Attribution license (http://creativecommons.org/licenses/by/4.0/). 